\title{
Effect of soil mineralogy on potassium fixation in soils developed on different parent material
}

\author{
Ester Portela ${ }^{\mathrm{a}}$, Fernando Monteiro ${ }^{\mathrm{b}}$, Madalena Fonseca ${ }^{\mathrm{b}}$, Maria Manuela Abreu $^{\mathrm{c}, *}$ \\ ${ }^{a}$ Departamento de Biologia e Ambiente, Centro de Investigação e Tecnologias Agro-Ambientais e Biológicas (CITAB), Universidade de Trás-os-Montes e Alto Douro, 5001- \\ 801 Vila Real, Portugal \\ ${ }^{\mathrm{b}}$ Instituto Superior de Agronomia, Universidade de Lisboa, Forest Research Centre (CEF), Tapada da Ajuda, 1349-017 Lisboa, Portugal \\ ${ }^{\mathrm{c}}$ Instituto Superior de Agronomia, Universidade de Lisboa, Linking Landscape, Environment, Agriculture and Food Research Centre (LEAF), Tapada da Ajuda, $1349-017$ \\ Lisboa, Portugal
}

\section{A R T I C L E I N F O}

\section{Handling Editor: Edward A Nater}

Keywords:

Potassium fixation

Soil mineralogy

$\mathrm{X}$-ray diffraction

Soil-size fractions

Vermiculites

\begin{abstract}
A B S T R A C T
Potassium release from weathering of soil minerals may support the $\mathrm{K}$ nutrition of crops for many years. However, when soils become exhausted, the response to $\mathrm{K}$ fertilisation may be limited due to its fixation in nonexchangeable forms, reducing the efficacy of $\mathrm{K}$ fertilisation. The present study examines the role of soil mineralogical composition on the $\mathrm{K}$ fixation characteristics of soils developed under a Mediterranean type of climate. Nine soils derived from different parent materials were collected in several regions of Portugal. Soil properties were determined, and clay, silt and fine-sand fractions were studied by X-ray diffraction. Potassium fixation was determined after the soil samples had been treated with increasing rates of $\mathrm{K}$ application. The amount of $\mathrm{K}$ fixed was obtained by difference, measuring the amount of $\mathrm{K}$ remaining extractable by ammonium acetate.

The soils under study showed a relatively high $\mathrm{K}$ fixation capacity, varying between 30 and $80 \%$ for an application rate equivalent to $800 \mathrm{~kg} \mathrm{Kha}^{-1}$. Soils with high $\mathrm{K}$ fixation capacity were derived from gabbros, gabbrodiorites and quarzdiorites, and had relevant amounts of vermiculites and/or interstratified mica-vermiculite minerals, either in the clay or in the silt and fine sand fractions.

Soils rich in calcium carbonates also fix high amounts of K. These soils contain mica-illite minerals and are rich in some of the above-mentioned minerals in the clay and silt fractions. While $\mathrm{K}$ fixation capacity is normally assumed to derive from minerals in the clay fraction, the results of this study show that vermiculites and/or interstratified mica-vermiculites present in the silt and fine sand fractions can contribute a significant proportion of the total $\mathrm{K}$ fixation capacity and, thus, these size fractions should also be included in any assessment of $\mathrm{K}$ fixation capacity.
\end{abstract}

\section{Introduction}

Weathering of soil minerals has supported nutrition of plants for many centuries worldwide, particularly through the release of potassium. However, weathering of primary minerals is not a permanent, endless source for crops, and, in some production systems with a restricted input of K, may limit long-term soil fertility. The decrease of soil fertility, occurs throughout the world, and fertile soil resources are rapidly depleted, reducing the potential for food production (Keesstra et al., 2016).

Plants may feed from interlayer $\mathrm{K}$, particularly in soils rich in micaceous minerals (Portela, 1993). However, interlayer K may be exhausted, as has been shown by many studies worldwide (Mengel and
Kirkby, 2001 and references therein), and the more the interlayer $\mathrm{K}$ is depleted the higher the fixation capacity becomes. As expected, the balance between K output mainly due to $\mathrm{K}$ uptake by crops, and input of $\mathrm{K}$ by fertiliser additions, greatly influences the $\mathrm{K}$ fixation capacity of soils, as demonstrated by Simonsson et al. (2009). Nevertheless, K fertilisation may become ineffective due to the fixation of $\mathrm{K}$ in nonexchangeable form, only a small fraction of which may be recovered by plants (Cassman et al., 1989; Mengel and Kirkby, 2001).

Potassium application in soils depleted in this nutrient, or in soils poor in K-rich minerals, results in its fixation by the transfer of $\mathrm{K}$ from the soil solution to specific sites of some 2:1 phyllosilicate layers, causing their collapse. The site-specific fixation of $\mathrm{K}$ is made possible by the geometry of the fixation sites and the size of the $\mathrm{K}$ ions. Potassium

\footnotetext{
* Corresponding author.

E-mail addresses: eportela@utad.pt (E. Portela), manuelaabreu@isa.ulisboa.pt (M.M. Abreu).
} 
ions are entrapped in the ditrigonal holes of the facing interlayer oxygen planes between the 2:1 layers of phyllosilicates (Rich, 1968). It is generally accepted that the phyllosilicates chiefly responsible for the fixation of $\mathrm{K}$ are vermiculites, weathered mica/illite minerals and interstratified phases containing the above-mentioned minerals (Douglas, 1989; Fanning et al., 1989).

In the last two decades cereals have been increasingly replaced by olive orchards in agricultural land all over the country. In the southern part of the country, the response to $\mathrm{K}$ fertilisation has been unexpectedly low or even non-existent (Almeida, 1958; Alves et al., 1979). For instance, in olive trees, despite the K deficiency symptoms observed and the occurrence of deficient foliar $\mathrm{K}$ concentrations, no response was obtained when current rates of $\mathrm{K}$ were applied. With normal rates of $\mathrm{K}$ fertilisation a delayed response occurred only after eight consecutive years of application (Marcelo, 2001). In addition, in soils derived from calcareous materials, very high rates of $\mathrm{K}$ fertilisation (1330 $\mathrm{kg} \mathrm{K} \mathrm{ha}^{-1}$ ) were needed to obtain a significant increase in olive production (Jordão et al., 2009). Thus, the lack of response to K application, may be explained if $\mathrm{K}$ fixation occurs.

Ammonium acetate solution, which extracts both soluble and exchangeable $\mathrm{K}$ is the most widely used reagent as a method of estimating plant 'available' $\mathrm{K}$ in order to develop $\mathrm{K}$ fertiliser recommendations (Novozamsky and Houba, 1987). Though this method has been systematically used, the ammonium acetate extractant is apparently inappropriate for soils prone to $\mathrm{K}$ fixation. The current fertility classes used in Portugal are also inadequate (Jordão et al., 2009) and the usual rates of $\mathrm{K}$ fertilisation appear to be too low to raise the concentration of $\mathrm{K}$ in soil solution to meet the crop requirement. Therefore there is a necessity, for advisory purposes, to select the agricultural areas, were soils must be submitted to K fixation tests.

Most $\mathrm{K}$ fixation studies are focused on soils derived from calcareous materials (Dhaliwal et al., 2006; Najafi-Ghiri and Abtahi, 2013; Schneider, 1997), alluvium or other quaternary sediments (Barré et al., 2008; Murashkina et al., 2007a, 2007b; Simonsson et al., 2007, 2009). Few studies have been addressed to soils developed on intermediate/ mafic magmatic or metamorphic rocks in regions with a Mediterranean type of climate. Under these conditions, primary minerals are often partially weathered in illite and vermiculite type minerals occurring in both silt and sand fractions (Abreu and Vairinho, 1990; Fonseca et al., 2002; Monteiro et al., 2002; Velde and Meunier, 2008).

In studies of $\mathrm{K}$ fixation much of the emphasis has been placed on the clay fraction $(<2 \mu \mathrm{m})$ of the soil and its mineralogical composition (Barré et al., 2008; Sharpley, 1990). However, according to Murashkina et al. (2007a, 2007b), Najafi-Ghiri and Abtahi (2013) and Simonsson et al. (2009) the weathered minerals present in the silt and sand fractions play a crucial role in soil $\mathrm{K}$ fixation. Based on the studies of Abreu and Vairinho (1990), Fonseca et al. (2002) and Monteiro et al. (2002) these two fractions should also be considered, as they may play an important role in $\mathrm{K}$ fixation in Portuguese soils. A better understanding of the $\mathrm{K}$ fixation potential, as well as the role of the mineralogy of the different size fractions of soils developed on several parent materials is therefore needed. Then, the main objective of this study is to assess the $\mathrm{K}$ fixation characteristics of soils developed under a Mediterranean type of climate on sedimentary rocks (limestones, sandstones and arkoses), and intermediate/mafic magmatic or metamorphic rocks, in order to achieve a better understanding of $\mathrm{K}$ fixation in these kinds of soils.

\section{Materials and methods}

\subsection{Soils}

Nine soils formed on different parent materials and with a wide textural span were selected. Soils were collected at several latitudes, from the north to the south of Portugal, the last four samples from the Alentejo region (soils AZ, LG, VA, BL; Fig. 1). Their locations, parent materials and soil classification by IUSS Working Group WRB (2006) are listed in Table 1. Most of the soils occur in landscapes characterized by gently to very gently slope gradients (1-5\%) except soil DG, which is in a sloping (5-10\%) location. The soils are located in regions with a Mediterranean type of climate, Csa and Csb climate groups, after Köppen (Iberian Climate Atlas, 2011). The land use is rain-fed olive orchards, and/or cereal grains in the Alentejo region. The rates of $\mathrm{P}$ and $\mathrm{K}$ fertilisation are nil or very low.

Soil samples were taken from the surface or subsurface layers to a maximum depth of $50 \mathrm{~cm}$ to avoid layers rich in organic matter. The role of the subsurface layer in $\mathrm{K}$ fixation has long been established and its importance for K uptake has been demonstrated by Beringer (1985) and Kuhlmann (1990). The soils were taken wet, crushed by hand, airdried and sieved at $2 \mathrm{~mm}$, and the coarse fraction $(>2 \mathrm{~mm}$ ) was quantified by weight. Fine fraction $(<2 \mathrm{~mm})$ was analysed in duplicate for physical and chemical soil properties, and the data were referred to oven dry $\left(105^{\circ} \mathrm{C}\right)$ soil mass. Particle size distribution was determined by sieving and sedimentation (pipette method), after oxidation of organic matter with $\mathrm{H}_{2} \mathrm{O}_{2}$, removal of carbonates with $10 \% \mathrm{HCl}$ (soils S1 and S5), dispersion by Na-hexametaphosphate, and overnight agitation in a reciprocal shaker; $\mathrm{pH}$ was measured in $\mathrm{H}_{2} \mathrm{O}$ and $\mathrm{KCl} 1 \mathrm{~mol} \mathrm{~L}^{-1}$ with a 1:2.5 soil solution ratio; organic carbon was determined by oxidation with $\mathrm{K}_{2} \mathrm{Cr}_{2} \mathrm{O}_{7}$, following the modified Walkley-Black method; $\mathrm{P}$ extractable was measured by colorimetric method after extraction with ammonium lactate-acetic acid solution at pH 3.7 (Riehm, 1958); the extractable cations ( $\mathrm{Ca}, \mathrm{Mg}, \mathrm{K}$ and $\mathrm{Na}$ ) were determined with $1 \mathrm{~mol} \mathrm{~L}^{-1}$ ammonium acetate at $\mathrm{pH} 7$ and the $\mathrm{H}+\mathrm{Al}$ by $1 \mathrm{~mol} \mathrm{~L}^{-1} \mathrm{KCl}$ method. The effective cation exchange capacity (CEC effective) was calculated from the sum of extractable cations plus extractable $\mathrm{H}+\mathrm{Al}$. Calcium carbonate was calculated after inorganic $\mathrm{C}$, which was obtained by subtraction of total C and organic C. Total C was determined in a Skalar Primacs TOC Analyser by oxidation at $1100{ }^{\circ} \mathrm{C}$ and the generated $\mathrm{CO}_{2}$ detected by a non-dispersive infrared detector; organic $\mathrm{C}$ was calculated by the system software (Primacs) from total $\mathrm{C}$ and inorganic $\mathrm{C}$, which was determined after $\mathrm{CO}_{2}$ produced by acidification of the sample.

For mineralogical analysis, clay $(<2 \mu \mathrm{m})$, silt $(2-20 \mu \mathrm{m})$ and fine sand $(20-200 \mu \mathrm{m})$ fractions were separated by sedimentation and decantation after dispersion, which included organic matter oxidation with $\mathrm{H}_{2} \mathrm{O}_{2}$ and overnight agitation in a reciprocal shaker after adjustment of the $\mathrm{pH}$ of the soil suspension to about 8.5 with $\mathrm{NaOH}$. To achieve a more complete separation of silt and sand fractions the decantation processes were performed 10 times. This procedure does not completely separate each one of those size fractions, but their remaining quantities are below the detection limit of XRD techniques.

The mineral components of clay were assessed by X-ray Diffraction (XRD) on oriented samples. In order to enhance the peak reflections of phyllosilicates, the mineralogy of silt and fine sand fractions was evaluated on samples deposited by settling from a liquid suspension on glass slides. The samples were $\mathrm{Mg}$ saturated with $1 \mathrm{~mol} \mathrm{~L}^{-1} \mathrm{MgCl}_{2}$, washed free of chlorides and scanned from 2 to $65^{\circ} 2 \theta$ after air drying. To determine the nature of the expandable minerals scannings were also made from 2 to $20^{\circ} 2 \theta$ after $\mathrm{K}$ saturation, heating and ethylene glycol solvation, following the procedures of Schultz (1969). The XRD scans were performed using $\mathrm{Cu}$ k $\alpha$ radiation $(40 \mathrm{kV}, 30 \mathrm{~mA})$ and a scan rate of $0.02{ }^{\circ} 2 \theta \mathrm{s}^{-1}$ for clay and $0.04^{\circ} 2 \theta \mathrm{s}^{-1}$ for silt and fine sand. A Philips PW 1050 X-ray diffractometer was used.

Mineral identification was performed by comparing measured basal space values with those tabulated in JCPDS files (JCPDS-ICDD, 1996), following usual procedures as indicated by Moore and Reynolds (1997) and Sawhney (1989). Semi-quantitative assessment of the identified minerals was made on non-oriented mounts of clay, silt and ground fine sand and based on the integrated area of their main XRD reflections, taking into account the mean values of the reflective power generally indicated for these minerals, using the software MacDiff v. 4.2.5, written by R. Petschic. 


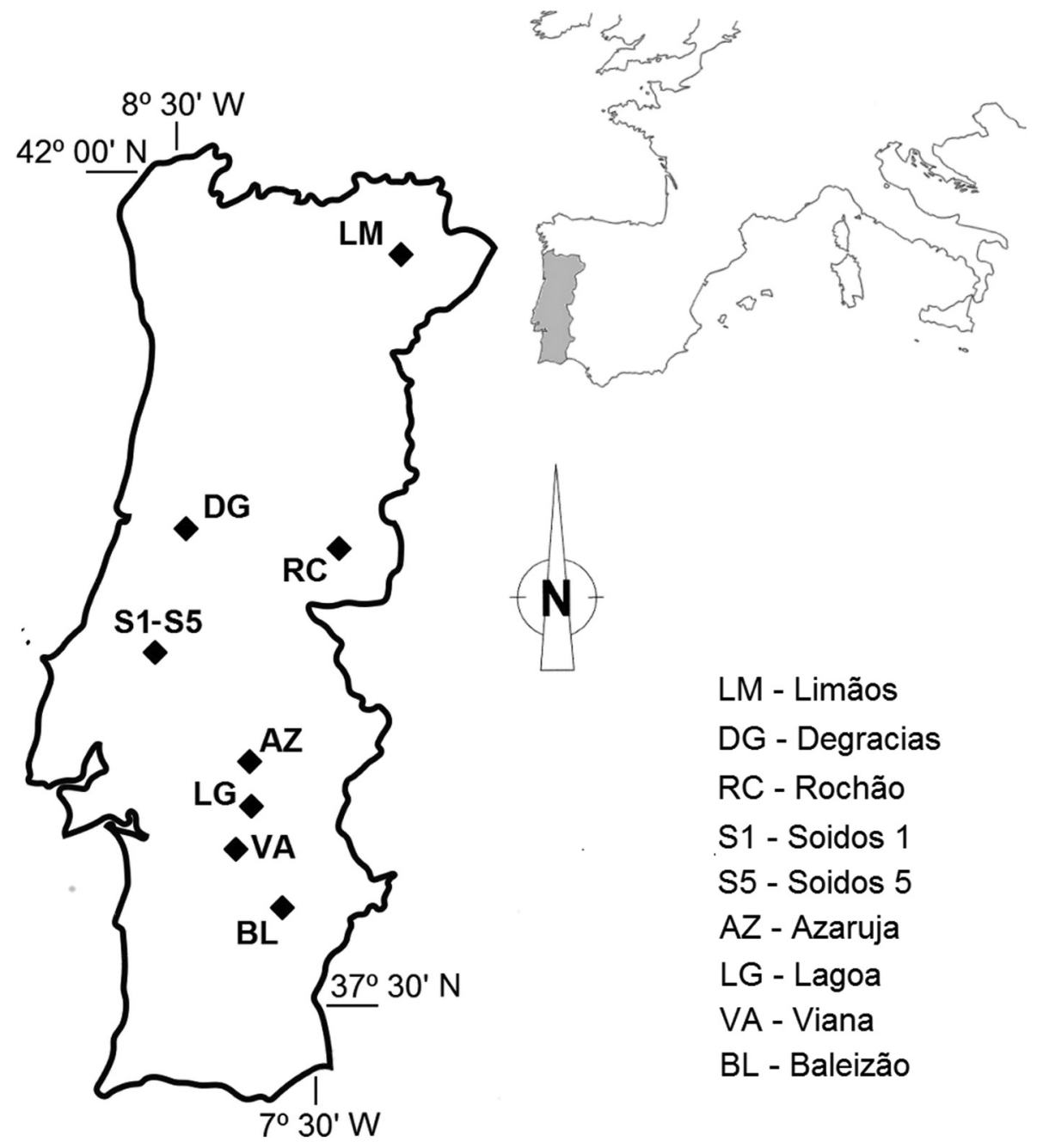

Fig. 1. Location of the nine soils under study.

Table 1

Location, parent material and classification of the soils under study.

\begin{tabular}{|c|c|c|c|c|c|}
\hline Soils & Location & $\begin{array}{l}\text { Geographical } \\
\text { coordinates }\end{array}$ & Parent material & Mineralogical composition & $\begin{array}{l}\text { Classification (IUSS Working } \\
\text { Group, 2006) }\end{array}$ \\
\hline Limãos (LM) & $\begin{array}{l}\text { Salselas (Macedo de } \\
\text { Cavaleiros) }\end{array}$ & $\begin{array}{l}6^{\circ} 50^{\prime} 32.5^{\prime \prime} \mathrm{W} \\
41^{\circ} 31^{\prime} 26.3^{\prime \prime} \mathrm{N}\end{array}$ & Amphibolites & $\begin{array}{l}\text { Amphibole, Ca plagio-clase, chlorite, } \\
\text { quartz, pyroxene and sphene }\end{array}$ & Vertic Cambisol (Eutric) \\
\hline Degracias (DG) & Degracias (Soure) & $\begin{array}{l}8^{\circ} 26^{\prime} 28,3^{\prime \prime} \mathrm{W} \\
40^{\circ} 1^{\prime} 19.4^{\prime \prime} \mathrm{N}\end{array}$ & $\begin{array}{l}\text { Sandstones and } \\
\text { limestones }\end{array}$ & Quartz, feldspar, mica, calcite and kaolinite & Haplic Luvisol (Chromic) \\
\hline Rochão (RC) & Ladoeiro (Idanha-a-Nova) & $\begin{array}{l}7^{\circ} 18^{\prime} 16,0^{\prime \prime} \mathrm{W} \\
39^{\circ} 51^{\prime} 11.5^{\prime \prime} \mathrm{N}\end{array}$ & Arkoses & Quartz, feldspar, mica and kaolinite & Haplic Luvisol (Abruptic) \\
\hline Soidos 5 (S5) & Abitureiras (Santarém) & $\begin{array}{l}8^{\circ} 45^{\prime} 30.7^{\prime \prime} \mathrm{W} \\
39^{\circ} 18^{\prime} 52.7^{\prime \prime} \mathrm{N}\end{array}$ & Limestones and marls & Calcite, clay and small amounts of quartz & Hypocalcic Calcisol (Siltic) \\
\hline Soidos 1 (S1) & Abitureiras (Santarém) & $\begin{array}{l}8^{\circ} 45^{\prime} 22.7^{\prime \prime} \mathrm{W} \\
39^{\circ} 18^{\prime} 53.6^{\prime \prime} \mathrm{N}\end{array}$ & Limestones and marls & Calcite, clay and small amounts of quartz & Hypocalcic Calcisol (Siltic) \\
\hline Azaruja (AZ) & $\mathrm{St}^{\mathrm{a}}$ Justa (Arraiolos) & $\begin{array}{l}7^{\circ} 50^{\prime} 35.3^{\prime \prime} \mathrm{W} \\
38^{\circ} 44^{\prime} 58.2^{\prime \prime} \mathrm{N}\end{array}$ & Quartzdiorites & Plagioclase, amphibole, biotite and quartz & $\begin{array}{l}\text { Haplic Luvisol (Abruptic, } \\
\text { Endosodic) }\end{array}$ \\
\hline Lagoa (LG) & $\mathrm{N}^{\mathrm{a}} \mathrm{Sr}^{\mathrm{a}}$ Machede (Évora) & $\begin{array}{l}7^{\circ} 49^{\prime} 24.5^{\prime \prime} \mathrm{W} \\
38^{\circ} 32^{\prime} 20.8^{\prime \prime} \mathrm{N}\end{array}$ & Gabbrodiorites & $\begin{array}{l}\text { Feldspar, amphibole, biotite and small } \\
\text { amounts of quartz }\end{array}$ & $\begin{array}{l}\text { Haplic Luvisol (Abruptic, } \\
\text { Sodic) }\end{array}$ \\
\hline Viana (VA) & $\begin{array}{l}\text { Viana do Alentejo (Viana } \\
\text { do Alentejo) }\end{array}$ & $\begin{array}{l}8^{\circ} 2^{\prime} 28.7^{\prime \prime} \mathrm{W} \\
38^{\circ} 19^{\prime} 59.6^{\prime \prime} \mathrm{N}\end{array}$ & Metagabbros & $\begin{array}{l}\text { Ca plagioclase, amphibole, pyroxene, biotite } \\
\text { and small amounts of quartz }\end{array}$ & Haplic Luvisol (Sodic) \\
\hline Baleizão (BL) & Baleizão (Beja) & $\begin{array}{l}7^{\circ} 43^{\prime} 0.4^{\prime \prime} \mathrm{W} \\
38^{\circ} 0^{\prime} 51.7^{\prime \prime} \mathrm{N}\end{array}$ & Gabbros & $\begin{array}{l}\text { Ca plagioclase, pyroxene, amphibole and } \\
\text { Ti/Fe oxides }\end{array}$ & Haplic Vertisol (Eutric) \\
\hline
\end{tabular}

\subsection{Soil $K$ pools and measurement of $K$ fixation}

The following soil $\mathrm{K}$ pools were determined: soil solution $\mathrm{K}$ (Ksol), extractable $\mathrm{K}$ (Kextr) and fixed $\mathrm{K}$ (Kfixed). The $\mathrm{K}$ in aqueous solution (Ksol) was obtained by the displacement column procedure (Adams,
1974). Extractable K was extracted with $1 \mathrm{~mol} \mathrm{~L}^{-1}$ ammonium acetate at $\mathrm{pH} 7$ in air-dried soils samples. Potassium in the extracts was measured by EEL flame photometer. Analyses were performed in duplicate.

Potassium fixed by phyllosilicates is conventionally determined with an ammonium salt, which is also the most widely used method of 
Table 2

Some basic soil properties of the nine soil samples.

\begin{tabular}{|c|c|c|c|c|c|c|c|c|c|}
\hline & LM & DG & $\mathrm{RC}$ & S5 & S1 & $\mathrm{AZ}$ & LG & VA & $\mathrm{BL}$ \\
\hline Soil depth $(\mathrm{cm})$ & $0-25$ & $20-50$ & $20-50$ & $15-35$ & $15-35$ & $0-25$ & $0-25$ & $0-25$ & $0-25$ \\
\hline Coarse fraction $(\%, m / m)$ & 0 & 3 & 33 & 29 & 35 & 46 & 8 & 25 & 30 \\
\hline Clay $\left(\mathrm{g} \mathrm{kg}^{-1}\right)$ & 327 & 442 & 288 & 267 & 264 & 237 & 149 & 140 & 540 \\
\hline Silt $\left(\mathrm{g} \mathrm{kg}^{-1}\right)$ & 138 & 312 & 61 & 482 & 480 & 95 & 106 & 30 & 210 \\
\hline Fine sand $\left(\mathrm{g} \mathrm{kg}^{-1}\right)$ & 378 & 220 & 144 & 99 & 100 & 531 & 409 & 548 & 202 \\
\hline Coarse sand $\left(\mathrm{g} \mathrm{kg}^{-1}\right)$ & 157 & 25 & 507 & 153 & 156 & 138 & 335 & 282 & 47 \\
\hline $\mathrm{pH}\left(\mathrm{H}_{2} \mathrm{O}\right)$ & 6.5 & 7.1 & 5.3 & 7.8 & 8.1 & 5.7 & 7.2 & 7.0 & 7.0 \\
\hline $\mathrm{pH}(\mathrm{KCl})$ & 5.0 & 6.3 & 3.5 & 7.1 & 7.2 & 3.9 & 5.5 & 4.7 & 5.6 \\
\hline Organic carbon $\left(\mathrm{g} \mathrm{kg}^{-1}\right)$ & 6.1 & 6.0 & 1.5 & 13.8 & 8.4 & 5.8 & 4.5 & 3.7 & 6.3 \\
\hline $\mathrm{P}$ extractable $\left(\mathrm{mg} \mathrm{kg}^{-1}\right)$ & 4.0 & 0.7 & 1.4 & 9.6 & 1.9 & 20.9 & 46.7 & 2.3 & 50.9 \\
\hline $\mathrm{K}$ in soil solution $\left(\mathrm{mg} \mathrm{L}^{-1}\right)$ & 1.50 & 0.70 & 3.50 & 1.60 & 0.90 & 2.60 & 3.40 & 2.15 & 0.60 \\
\hline Buffer power ${ }^{a}$ & 15 & 56 & 5 & 9 & 8 & 4 & 6 & 4 & 15 \\
\hline \multicolumn{10}{|c|}{ Extractable cations $\left(\mathrm{cmol}_{\mathrm{c}} \mathrm{kg}^{-1}\right)$} \\
\hline $\mathrm{Ca}$ & 8.61 & 17.52 & 8.05 & 35.28 & 26.40 & 10.40 & 9.92 & 8.32 & 31.52 \\
\hline $\mathrm{Mg}$ & 10.93 & 0.64 & 4.13 & 0.99 & 0.67 & 2.00 & 3.47 & 3.60 & 10.93 \\
\hline $\mathrm{K}$ & 0.16 & 0.40 & 0.18 & 0.29 & 0.14 & 0.08 & 0.11 & 0.08 & 0.10 \\
\hline $\mathrm{Na}$ & 0.17 & 0.49 & 0.21 & 0.17 & 0.07 & 0.13 & 0.43 & 0.65 & 0.44 \\
\hline $\mathrm{H}+\mathrm{Al}$ & 0.10 & 0.00 & 2.40 & 0.00 & 0.00 & 0.28 & 0.09 & 0.00 & 0.00 \\
\hline CEC effective ${ }^{\mathrm{b}}\left(\mathrm{cmol}_{\mathrm{c}} \mathrm{kg}^{-1}\right)$ & 19.96 & 19.04 & 14.98 & 36.72 & 27.27 & 12.89 & 14.01 & 12.64 & 42.99 \\
\hline $\mathrm{CaCO}_{3}\left(\mathrm{~g} \mathrm{~kg}^{-1}\right)$ & 0 & 0 & 0 & 159 & 194 & 0 & 0 & 0 & 0 \\
\hline
\end{tabular}

a In the linear part of the buffer curve.

b Effective cation exchange capacity.

estimating plant available K (Novozamsky and Houba, 1987). Its quantification relies on a procedure in which the applied $\mathrm{K}$ not replaced by the ammonium cation corresponds to the fixed K. Potassium fixation was determined after the soil samples had been treated with increasing rates of $\mathrm{K}$ application. The amounts of $\mathrm{K}$ fixed were obtained by difference, measuring the amounts of $\mathrm{K}$ remaining extractable by ammonium ions as follows:

fixed $\mathrm{K}=\mathrm{K}$ applied $+\mathrm{K}$ before treatment $-\mathrm{K}$ extractable after treatment

The following amounts of $\mathrm{K}$ (as $\mathrm{KCl}$ ) were added to $1 \mathrm{~kg}$ of each soil (oven-dry basis): 0, 25, 50, 100, 200, 400 and $800 \mathrm{mg}$ of $\mathrm{K}$, with the exceptions of soils RC, AZ, LG, and VA, in which the highest level of $\mathrm{KCl}$ was excluded, because of their low effective CEC $\left(<15 \mathrm{cmol}_{\mathrm{c}} \mathrm{kg}^{-1}\right.$, Tables 2 and 3 ) and the high content of total sand, which could cause excessive $\mathrm{K}$ concentrations in soil solution. All soils were incubated wet, near 'field capacity' (from 10 to $50 \mathrm{kPa}$ ) at $22{ }^{\circ} \mathrm{C}$ for 60 days, and water content was maintained constant throughout the incubation period. After incubation, the soil samples were allowed to air-dry, and Kextr and Ksol were determined again. It is possible that the air drying step increased the amount of $\mathrm{K}$ fixed, as this issue seems to be dependent on the level of extractable K (Bouabid et al., 1991; Dowdy and Hutcheson, 1963; Sardi and Csitari, 2008).

Buffer power of the soils for $\mathrm{K}$ was calculated according to Kovar and Barber (1990) using the ratio between K exchangeable (Kex) and Ksol. Since ammonium acetate extracts both exchangeable $\mathrm{K}$ and $\mathrm{K}$ in solution, the values of Kextr were subtracted by $\theta$ Ksol, where $\theta$ is the volumetric water content per $\mathrm{cm}^{3}$ expressed in $\mu \mathrm{mol} \mathrm{cm}{ }^{-3}$ of soil and Ksol was expressed in $\mu \mathrm{mol} \mathrm{cm}{ }^{-3}$ (that is, Kex $=\mathrm{K}$ extractable with ammonium acetate $-\theta \mathrm{K}$ in soil solution). The values of $\mathrm{K}$ buffer power were calculated from the slope of the relation $\Delta \mathrm{Kex} / \Delta \mathrm{Ksol}$ in the linear portion of the buffer curve.

\subsection{Statistical tests}

The relationships between soil characteristics and the maximum amount of fixed $\mathrm{K}$, and $\mathrm{K}$ additions and forms of $\mathrm{K}$ in the soil (solution $\mathrm{K}$, extractable $\mathrm{K}$, fixed $\mathrm{K}$ ) were carried out and linear regressions were applied where appropriate, according to standard statistical tests (program XLSTAT.2016).

\section{Results}

\subsection{Soil characteristics}

The soils under study (Table 1 and Fig. 1) include a range of textures, from sandy loam to clay (Table 2), with a large variation in the contents of silt (30-482 $\left.\mathrm{g} \mathrm{kg}^{-1}\right)$ and fine sand (99-548 $\mathrm{g} \mathrm{kg}^{-1}$ ). Soils LM, DG and BL have the highest content of clay and soils VA and LG the lowest. Soils S1 and S5, the two carbonate-rich soils, have the largest silt content and values of $\mathrm{pH}$. The soils are poor in organic carbon and phosphorus, and only two are acid (soils RC and AZ). All the soils have an extremely low $\mathrm{K}$ concentration in the soil solution $\left(0.7-3.5 \mathrm{mg} \mathrm{L}^{-1}\right)$, which is far below the level needed for ryegrass growth (8-22 $\mathrm{mg} \mathrm{K} \mathrm{L}^{-1}$ ), based on the data of Portela (1993) or cereal growth under field conditions (20-40 $\mathrm{mg} \mathrm{K} \mathrm{L}^{-1}$ ) (Beringer, 1985). However, according to the current national soil fertility classes for $\mathrm{K}$ supply (LQARS, 2000), which are based on $\mathrm{NH}_{4}{ }^{+}$extraction, these soils would be classified as medium to high.

The effect of addition to the soils of progressive amounts of $\mathrm{K}$ on the values of $\mathrm{K}$ reached in soil solution, extractable $\mathrm{K}$ and fixed $\mathrm{K}\left(\mathrm{mg} \mathrm{kg}^{-1}\right.$, $\%)$ are presented in Table 3, as well as the parameters of the respective statistical analysis. There is a significant linear relationship between the added $\mathrm{K}$ and these three $\mathrm{K}$ pools, irrespective of the initial concentration of extractable $\mathrm{K}\left(0.08-0.40 \mathrm{cmol}_{\mathrm{c}} \mathrm{kg}^{-1}\right.$, Table 2).

The greatest relative increase in Ksol per unit of added $\mathrm{K}$ occurred in soils with low buffer power (also low CEC) (soils RC, VA, LG and AZ) and, as expected, the lowest increase occurred in soil DG, which has the highest K buffer power (56, Table 2). Soil RC attains the highest concentration of $\mathrm{K}$ in soil solution for all rates of $\mathrm{K}$ applied (Table 3). The variation in fixed $\mathrm{K}$ was large, ranging from 5 to $129 \mathrm{mg} \mathrm{kg}^{-1}$ (soil RC) and from 19 to $582 \mathrm{mg} \mathrm{kg}^{-1}$ (soil S5) for the lowest and the highest level of $\mathrm{K}$ application respectively. Table 3 also shows that the potential fixation capacity $\left(\mathrm{mg} \mathrm{kg}^{-1}\right)$ of soils was not attained in any soil. This means that the highest rate of $\mathrm{K}$ applied in these experiments is still below the saturation point (the point above which additional inputs of $\mathrm{K}$ do not yield further increment in $\mathrm{K}$ fixation). However, as far as crop growth is concerned, adequate levels of $\mathrm{K}$ concentration in soil solution were attained (20-40 $\mathrm{mg} \mathrm{L}^{-1}$ as stated above) in all soils for these application rates (Table 3).

In all nine soils the maximum amount of fixed $\mathrm{K}$ is correlated with the silt content $\left(y=0.965 x-114.4, R^{2}=0.512,{ }^{*} P<0.05\right)$ and with 
Table 3

Effect of increasing rates of $\mathrm{K}$ application on soil $\mathrm{K}$ pools: soil solution, extractable $\mathrm{K}$ and $\mathrm{K}$ fixation capacity (mg $\mathrm{kg}^{-1}$ and \% of $\mathrm{K}$ added). The regression coefficients and parameters of linear regression analysis between $\mathrm{K}$ added and $\mathrm{K}$ pools are included.

\begin{tabular}{|c|c|c|c|c|c|c|c|c|c|c|}
\hline \multirow[t]{2}{*}{ Soils } & & \multicolumn{6}{|c|}{ Potassium added ( $\mathrm{mg} \mathrm{kg}^{-1}$ of soil) } & \multirow[t]{2}{*}{$\mathrm{R}^{2}$} & \multirow[t]{2}{*}{ Slope } & \multirow[t]{2}{*}{ Intercept } \\
\hline & & 25 & 50 & 100 & 200 & 400 & 800 & & & \\
\hline \multirow[t]{4}{*}{ LM } & Ksol $\left(\mathrm{mg} \mathrm{L}^{-1}\right)$ & 2.6 & 3.4 & 7.2 & 17.0 & 40.7 & 95.6 & 0.99 & 0.12 & -2.76 \\
\hline & $\operatorname{Kextr}\left(\mathrm{mg} \mathrm{kg}^{-1}\right)$ & 91 & 108 & 141 & 219 & 343 & 610 & 1.00 & 0.67 & +75.8 \\
\hline & Kfixed (mg kg $\left.{ }^{-1}\right)$ & 7 & 16 & 33 & 55 & 131 & 264 & 1.00 & 0.34 & -2.77 \\
\hline & Kfixed (\%) & 30 & 32 & 33 & 27 & 33 & 33 & & & \\
\hline \multirow[t]{4}{*}{ DG } & Ksol $\left(\mathrm{mg} \mathrm{L}^{-1}\right)$ & 0.7 & 1.2 & 1.7 & 3.2 & 9.3 & 66.3 & 0.87 & 0.08 & -5.67 \\
\hline & Kextr $\left(\mathrm{mg} \mathrm{kg}^{-1}\right)$ & 158 & 170 & 215 & 277 & 396 & 706 & 0.99 & 0.69 & +141.0 \\
\hline & Kfixed (mg kg $\left.{ }^{-1}\right)$ & 23 & 36 & 41 & 79 & 160 & 250 & 0.98 & 0.30 & +19.5 \\
\hline & Kfixed (\%) & 93 & 72 & 41 & 39 & 40 & 31 & & & \\
\hline \multirow[t]{4}{*}{$\mathrm{RC}$} & Ksol $\left(\mathrm{mg} \mathrm{L}^{-1}\right)$ & 7.7 & 13.4 & 24.7 & 49.2 & 150.0 & & 0.96 & 0.36 & -5.52 \\
\hline & Kextr (mg kg $\left.{ }^{-1}\right)$ & 102 & 123 & 152 & 222 & 353 & & 1.00 & 0.67 & +85.6 \\
\hline & Kfixed (mg kg $\left.{ }^{-1}\right)$ & 5 & 9 & 30 & 60 & 129 & & 1.00 & 0.33 & -5.22 \\
\hline & Kfixed (\%) & 20 & 18 & 30 & 30 & 32 & & & & \\
\hline \multirow[t]{4}{*}{ S5 } & Ksol $\left(\mathrm{mg} \mathrm{L}^{-1}\right)$ & 2.3 & 3.1 & 4.3 & 7.9 & 23.7 & 71.0 & 0.96 & 0.09 & -3.07 \\
\hline & $\operatorname{Kextr}\left(\mathrm{mg} \mathrm{kg}^{-1}\right)$ & 153 & 156 & 167 & 190 & 235 & 364 & 0.99 & 0.27 & +141.3 \\
\hline & Kfixed (mg kg $\left.{ }^{-1}\right)$ & 19 & 41 & 80 & 157 & 312 & 582 & 1.00 & 0.73 & +7.44 \\
\hline & Kfixed (\%) & 77 & 81 & 80 & 79 & 78 & 73 & & & \\
\hline \multirow[t]{4}{*}{ S1 } & Ksol $\left(\mathrm{mg} \mathrm{L}^{-1}\right)$ & 2.2 & 4.0 & 8.9 & 27.3 & 82.9 & 162.0 & 0.99 & 0.21 & -5.98 \\
\hline & $\operatorname{Kextr}\left(\mathrm{mg} \mathrm{kg}^{-1}\right)$ & 94 & 111 & 132 & 184 & 299 & 445 & 0.99 & 0.46 & +90.8 \\
\hline & Kfixed (mg kg $\left.{ }^{-1}\right)$ & 22 & 30 & 59 & 107 & 192 & 446 & 0.99 & 1.83 & +1.50 \\
\hline & Kfixed (\%) & 86 & 59 & 59 & 53 & 48 & 56 & & & \\
\hline \multirow[t]{4}{*}{$\mathrm{AZ}$} & Ksol $\left(\mathrm{mg} \mathrm{L}^{-1}\right)$ & 5.2 & 8.0 & 17.5 & 28.2 & 61.7 & & 1.00 & 0.15 & +1.47 \\
\hline & $\operatorname{Kextr}\left(\mathrm{mg} \mathrm{kg}^{-1}\right)$ & 62 & 73 & 93 & 100 & 100 & & 0.63 & 0.12 & +63.7 \\
\hline & Kfixed (mg kg $\left.{ }^{-1}\right)$ & 9 & 23 & 53 & 146 & 346 & & 0.99 & 0.91 & -26.1 \\
\hline & Kfixed (\%) & 35 & 47 & 53 & 73 & 86 & & & & \\
\hline \multirow[t]{4}{*}{ LG } & Ksol $\left(\mathrm{mg} \mathrm{L}^{-1}\right)$ & 5.6 & 7.2 & 11.3 & 21.6 & 56.5 & & 0.97 & 0.13 & +0.57 \\
\hline & $\operatorname{Kextr}\left(\mathrm{mg} \mathrm{kg}^{-1}\right)$ & 67 & 74 & 87 & 108 & 141 & & 0.98 & 0.20 & +62.9 \\
\hline & Kfixed (mg kg $\left.{ }^{-1}\right)$ & 15 & 33 & 69 & 149 & 316 & & 1.00 & 0.80 & -8.21 \\
\hline & Kfixed (\%) & 60 & 67 & 69 & 75 & 79 & & & & \\
\hline \multirow[t]{4}{*}{ VA } & Ksol $\left(\mathrm{mg} \mathrm{L}^{-1}\right)$ & 3.7 & 5.5 & 7.1 & 23.5 & 69.5 & & 0.95 & 0.17 & -3.37 \\
\hline & $\operatorname{Kextr}\left(\mathrm{mg} \mathrm{kg}^{-1}\right)$ & 53 & 61 & 72 & 92 & 124 & & 0.98 & 0.20 & +48.5 \\
\hline & Kfixed (mg kg $\left.{ }^{-1}\right)$ & 14 & 31 & 70 & 150 & 318 & & 1.00 & 0.81 & -9.63 \\
\hline & Kfixed (\%) & 56 & 62 & 70 & 75 & 80 & & & & \\
\hline \multirow[t]{4}{*}{ BL } & Ksol $\left(\mathrm{mg} \mathrm{L}^{-1}\right)$ & 1.1 & 2.1 & 2.0 & 8.7 & 23.7 & 63.4 & 0.98 & 0.08 & -3.27 \\
\hline & $\operatorname{Kextr}\left(\mathrm{mg} \mathrm{kg}^{-1}\right)$ & 67 & 81 & 110 & 165 & 229 & 444 & 0.99 & 0.48 & +55.9 \\
\hline & Kfixed $\left(\mathrm{mg} \mathrm{kg}^{-1}\right)$ & 7 & 18 & 39 & 84 & 221 & 405 & 1.00 & 0.53 & -0.87 \\
\hline & Kfixed (\%) & 29 & 36 & 39 & 42 & 55 & 51 & & & \\
\hline
\end{tabular}

$\mathrm{pH}\left(\mathrm{H}_{2} \mathrm{O}\right)$ and $\mathrm{pH}(\mathrm{KCl})\left(\mathrm{R}^{2}=0.521\right.$, and $\mathrm{R}^{2}=0.525$, $* P<0.05$, respectively). It is worth noting that the largest silt content occurs in the two carbonate-rich soils. No significant correlations were found between maximum value of fixed $\mathrm{K}$ of each soil and other soil characteristics.

A relevant indicator to characterize the $\mathrm{K}$ fixation capacity of soils is the relationship between rates of added $\mathrm{K}$ and fixed $\mathrm{K}$ as a percentage of the added K, as shown in Fig. 2 and Fig. 3. Soils from the Alentejo

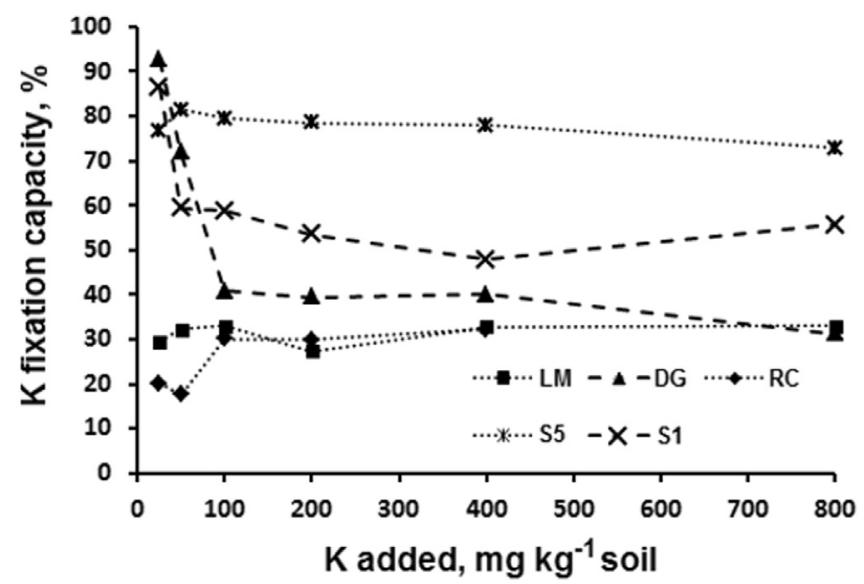

Fig. 2. Potassium fixation as a percentage of the added $\mathrm{K}$ for soils LM, DG, RC, S1 and S5.

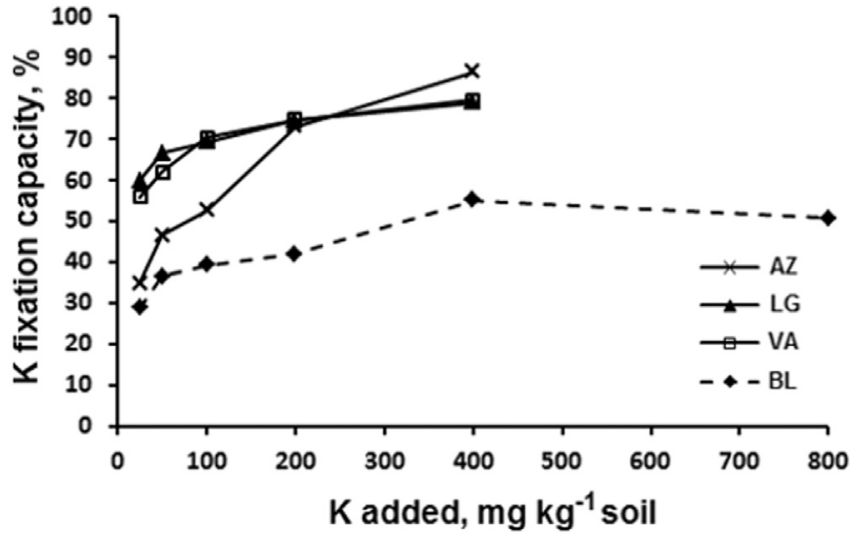

Fig. 3. Potassium fixation as a percentage of the added $\mathrm{K}$ for soils AZ, LG, VA and BL (Alentejo soils).

region (Fig. 3) have been grouped together because the pattern of variation in the four soils was similar. Soil BL differs from the other three soils (AZ, LG and VA) because the Ksol concentration is much lower for the same rate of $\mathrm{K}$ application, which is fully justified by its greater CEC (Table 2). The $\mathrm{K}$ fixation capacity (\%) of the soils can be considered high. For the application rate of $400 \mathrm{mg} \mathrm{K} \mathrm{kg}^{-1}$, the value of Kfixed was always higher than $30 \%$ in all soils. Furthermore, in soils S5, VA, LG and AZ a value of about $80 \%$ of Kfixed was reached. The patterns of variation between the rate of $\mathrm{K}$ application and fixation 
Table 4

Mineralogical composition of the clay fraction $(<2 \mu \mathrm{m})$ of the nine soils.

\begin{tabular}{|c|c|c|c|c|c|c|c|c|c|c|}
\hline & \multirow[t]{2}{*}{$\mathrm{Sm}$} & \multicolumn{2}{|l|}{$\mathrm{Vm}$} & \multirow[t]{2}{*}{ Int } & \multirow[t]{2}{*}{$\mathrm{Mi} / \mathrm{I}$} & \multirow[t]{2}{*}{ Kao } & \multirow[t]{2}{*}{ Cal } & \multirow[t]{2}{*}{ Go } & \multirow[t]{2}{*}{ Chl } & \multirow[t]{2}{*}{$\mathrm{Hm}$} \\
\hline & & Ss & Exp & & & & & & & \\
\hline LM & 1 & & & & $3 / 4$ & 4 & & & 5 & \\
\hline DG & 5 & $4 / 5$ & & 5 & $1 *$ & $2 / 3$ & & 4 & & \\
\hline $\mathrm{RC}$ & 2 & & & $2 / 3$ & & 3 & & 5 & & \\
\hline S5 & & 5 & 3 & 5 & $2 / 3^{*}$ & 3 & 3 & $4 / 5$ & & \\
\hline S1 & 3 & & & & $3^{*}$ & $3 / 4$ & 2 & & & \\
\hline $\mathrm{AZ}$ & & 4 & 4 & 3 & $3^{*}$ & 2 & & $4 / 5$ & & \\
\hline LG & 5 & 4 & & 3 & & 1 & & & & \\
\hline VA & 3 & 5 & & 3 & $4 *$ & 2 & & & 5 & \\
\hline BL & 1 & & & & 5 & 5 & & 5 & & 5 \\
\hline
\end{tabular}

Quantitative XRD analyses were performed on randomly-oriented samples (XRD patterns not shown). Sm: smectites; Vm: vermiculites: [Ss: sensu stricto (non-expandable); Exp: expandable until $1.65 \mathrm{~nm}$ ]; Int: interstratified micavermiculite minerals; $\mathrm{Mi} / \mathrm{I}$ : mica/illite and more or less weathered mica minerals (marked with *); Kao: kaolinite; Cal: calcite; Go: goethite; Chl: chlorite; $\mathrm{Hm}$ : hematite.

1: > 60\%; 2: 30-60\%; 3: 10-30\%; 4: 2-10\%; 5: <2\%

capacity are diverse, and the soils may be grouped in three categories: (i) soils DG and SD1, which initially exhibit a high percentage of Kfixed which drops and levels off with the increase of added $\mathrm{K}$ (dashed lines, Fig. 2); (ii) soils LM, RC and S5, whose fixation capacity remains about constant for all rates of added $\mathrm{K}$ (dotted lines, Fig. 2); and (iii) soils from the Alentejo region (AZ, LG, VA and BL), in which the percentage of Kfixed increases with progressive levels of $\mathrm{K}$ application, up to an application rate of $400 \mathrm{mg} \mathrm{kg}^{-1}$ (Fig. 3). Duplication of this rate may yield a plateau or a decrease in the fixation capacity, as suggested by the pattern of soil BL for the highest $\mathrm{K}$ application rate. However, for soils $\mathrm{AZ}, \mathrm{LG}$ and VA there is no indication that the percentage of Kfixed is approaching its maximum.

\subsection{Mineralogical analysis of the soil fractions}

Semi-quantitative mineralogical analysis of the clay fraction $(<2 \mu \mathrm{m})$ is presented in Table 4 , and the mineralogy of the silt $(2-20 \mu \mathrm{m})$ and fine sand $(0.02-0.2 \mathrm{~mm})$ fractions is shown in Table 5 .

Figure 4 shows the XR diagrams of the clay, silt and fine sand fractions of soil AZ. The identified phyllosilicates were grouped into kaolinites, smectites, vermiculites, mica/illite minerals, chlorites and interstratified mica-vermiculite minerals. As shown in Fig. $4 \mathrm{~A}$ and in Tables 4 and 5, vermiculites include non-expandable (vermiculite sensu stricto) and expandable phases until about $1.65 \mathrm{~nm}$ (expandable vermiculite or low-charge vermiculite according to Douglas, 1989 and Moore and Reynolds, 1997).

Smectites are present in the clay fraction of most of the studied soils, but their highest content ( $>60 \%$ ) occurs in the soils derived from amphibolites (soil LM) and gabbros (soil BL). Smectites may also occur in the silt fraction of LM and RC soils, but this may be due to an incomplete dispersion of that size fraction. Mica/Illite minerals together with interstratified mica-vermiculite minerals were recorded in the clay fraction of all soils in contents above $10 \%$, and are dominant ( $>60 \%$ ) in soil DG, which was developed on a complex of sandstones and limestones (Table 4). In this soil, and also in soils S1, S5, AZ and VA, the mica/illite minerals exhibit clear signs of weathering, as their main $\mathrm{XRD}$ reflection $(1 \mathrm{~nm})$ is broadened and shifted towards the higher $\mathrm{d}$ values as illustrated in Fig. 4A for soil AZ. Interstratified mica-vermiculite minerals were also identified in most of the soils in both the clay (2-30\%) and silt fractions (2-10\%) (Tables 4 and 5). With the exception of soil S1 (vermiculites completely absent), vermiculites occur in small amounts $(<10 \%)$ in all soils, either in the clay or in the silt fractions. Expandable vermiculites are also present, generally in percentages ranging from 2 to $30 \%$ (soils VA, LG, AZ and S5), or even above (soil
Table 5

Mineralogical composition of the silt $(2-20 \mu \mathrm{m})$ and fine sand $(20-200 \mu \mathrm{m})$ fractions of the nine soils.

\begin{tabular}{|c|c|c|c|c|c|c|c|c|c|c|c|c|c|}
\hline & \multirow[t]{2}{*}{$\mathrm{Sm}$} & \multicolumn{2}{|l|}{ Vm } & \multirow[t]{2}{*}{ Int } & \multirow[t]{2}{*}{$\mathrm{Mi} / \mathrm{I}$} & \multirow[t]{2}{*}{ Kao } & \multirow[t]{2}{*}{ Cal } & \multirow[t]{2}{*}{ Go } & \multirow[t]{2}{*}{ Chl } & \multirow[t]{2}{*}{$\mathrm{Hm}$} & \multirow[t]{2}{*}{$\mathrm{Qz}$} & \multirow[t]{2}{*}{ Fld } & \multirow[t]{2}{*}{ Amph } \\
\hline & & Ss & Exp & & & & & & & & & & \\
\hline \multicolumn{14}{|l|}{ Silt } \\
\hline LM & $2 / 3$ & $4 / 5$ & & & $4 / 5$ & 4 & & & 5 & 5 & 2 & 3 & 5 \\
\hline DG & & 5 & & & $3 / 4$ & 4 & & & & & 1 & $3 / 4$ & \\
\hline $\mathrm{RC}$ & 3 & 4 & & & 4 & 4 & & & & & 2 & 3 & \\
\hline S5 & & 5 & 4 & 5 & 3 & 4 & 3 & 5 & & & 2 & & \\
\hline S1 & & & & & $4 / 5$ & 5 & 2 & & & & 2 & & \\
\hline $\mathrm{AZ}$ & 4 & 4 & & 4 & 3 & 3 & & 5 & & & $2 / 3$ & 3 & \\
\hline LG & & 5 & 4 & 4 & 5 & 3 & & & 5 & & 3 & 3 & 3 \\
\hline VA & & 5 & 3 & 5 & 5 & 4 & & & 4 & 5 & 3 & 2 & 4 \\
\hline $\mathrm{BL}$ & & 5 & 2 & & 4 & 5 & & 5 & & 5 & $2 / 3$ & 3 & 5 \\
\hline \multicolumn{14}{|c|}{ Fine sand } \\
\hline LM & & & & & 5 & & & & & & 1 & 5 & \\
\hline DG & & & & & 5 & & & & & & 1 & 5 & \\
\hline $\mathrm{RC}$ & & & & & 5 & & & & & & 1 & 4 & \\
\hline S5 & & & & & & & & & & & 2 & & \\
\hline S1 & & & & & & & & & & & 3 & & \\
\hline $\mathrm{AZ}$ & & $4 / 5$ & & & 3 & 4 & 4 & & & & $1 / 2$ & 3 & \\
\hline LG & & 5 & & & 5 & 5 & 5 & & & & 1 & 3 & 4 \\
\hline VA & & & & & 5 & & & & & & 1 & 3 & 4 \\
\hline BL & & $4 / 5$ & & & & & & & & & 2 & 1 & 5 \\
\hline
\end{tabular}

Quantitative XRD analyses were performed on randomly-oriented samples (XRD patterns not shown). Sm: smectites; Vm: vermiculites: [Ss: sensu stricto (non-expandable); Exp: expandable until $1.65 \mathrm{~nm}$ ]; Int: interstratified micavermiculite minerals; Mi/I: mica/illite minerals; Kao: kaolinite; Cal: calcite; Go: goethite; Chl: chlorites; Hm: hematite; Qz: quartz; Fld: feldspars; Amph: amphiboles.

1: > 60\%; 2: 30-60\%; 3: 10-30\%; 4: 2-10\%; 5: <2\%.

BL), either in the clay or in the silt fractions. Kaolinite is present in all nine soils in both the clay and silt fractions, but is particularly high ( $>30 \%$ ) in the clay fraction of soils VA, AZ and LG, being dominant in soil LG. In addition to these phyllosilicates there are other minerals, such as calcite, which is high in the soils derived from limestones and marls (soils S1 and S5) in all the three fractions. Albeit in low percentages, the occurrence of vermiculites and mica/illite minerals in the fine sand of some soils (VA, LG and AZ) should be emphasized, because fine sand is the main fraction (about half of the $<2 \mathrm{~mm}$ soil particles) in these soils (Tables 2 and 5).

\section{Discussion}

The relationships between the added $\mathrm{K}$ and the $\mathrm{K}$ pools obtained for the nine soils seem to be simple, and described by linear regressions. However, the equilibrium relationships between the three $\mathrm{K}$ pools (Ksol, Kextr and Kfixed) are complex, and the concentrations of $\mathrm{K}$ reached in soil solution depend in each soil upon the K fixation capacity of the minerals and their CEC.

The soils under study show a low-K status, so they are considered poor or almost depleted in $\mathrm{K}$, exhibiting high $\mathrm{K}$ fixation capacity (about $30-80 \%$ of the added $\mathrm{K}$ ). Hence, the high potential to fix $\mathrm{K}$ is certainly the cause of the inefficacy of $\mathrm{K}$ fertilisation, as is confirmed in certain Portuguese soils, in which the normal fertiliser rates (50-200 kg K ha ${ }^{-1}$ ) applied to cereal grains or olive orchards have no influence on productivity (Alves et al., 1979; Marcelo, 2001). With the exception of soil RC, the least $\mathrm{K}$ fixing soil, all the other soils need a rate of $\mathrm{K}$ application of $200 \mathrm{mg} \mathrm{kg}^{-1}$ or above (soils DG, S5 and BL) to attain $\mathrm{K}$ concentrations in the soil solution high enough for crop growth, which correspond to rates of $\mathrm{K}$ application higher than the normal range under field conditions. Soils DG, S5 and BL require levels of $\mathrm{K}$ application of $400 \mathrm{mg} \mathrm{kg}^{-1}\left(\sim 800 \mathrm{~kg} \mathrm{~K} \mathrm{ha}^{-1}\right)$ or even higher. Although the rates of $\mathrm{K}$ application to some of these soils are apparently very high, the saturation of the minerals fixation sites must occur to a great 

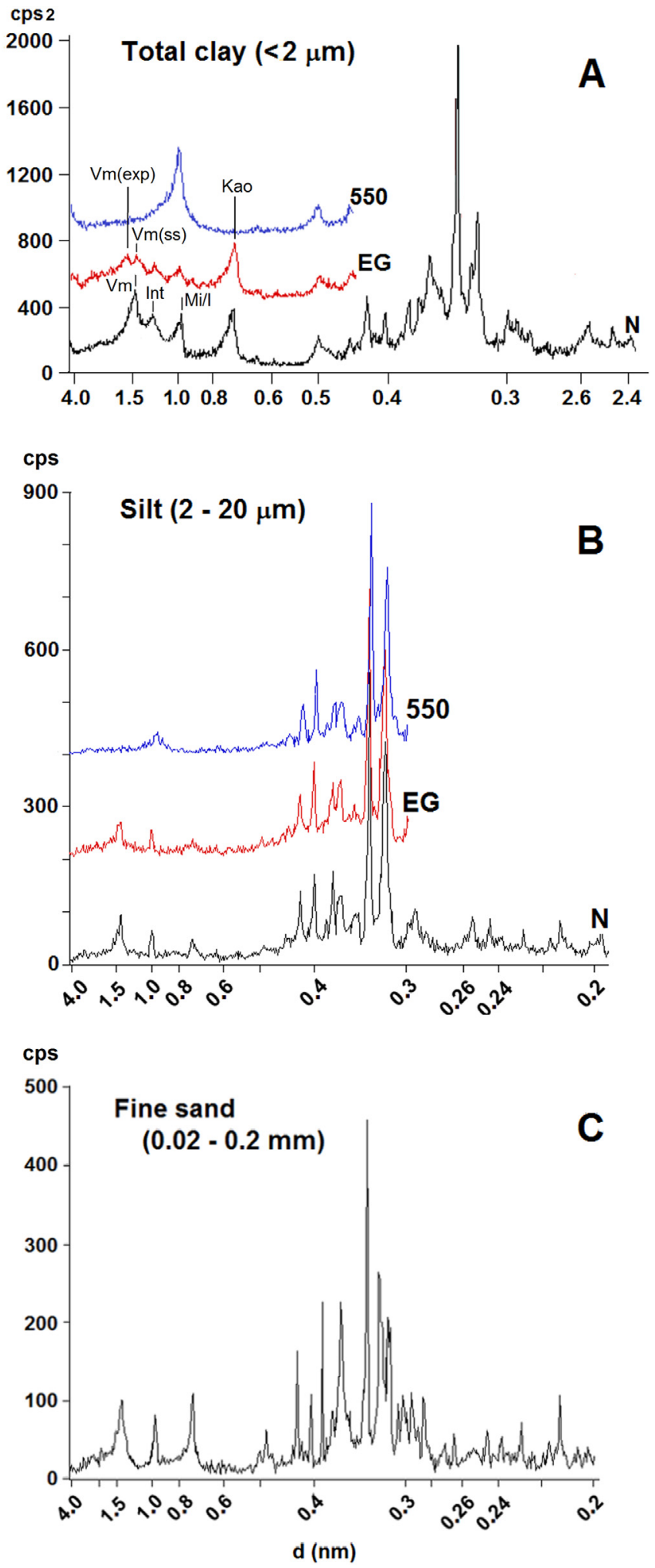

Fig. 4. X-ray diffraction patterns of soil AZ: (A) oriented samples of clay, and (B) silt and (C) fine sand fractions deposited by settling from a liquid suspension on glass slides. Scan rate was $0.02^{\circ} 2 \theta \mathrm{s}^{-1}$ for clay and $0.04^{\circ} 2 \theta \mathrm{s}^{-1}$ for silt and fine sand. $\mathrm{N}$ - air dried, Mg saturated sample; EG - Ethylene glycol solvated; 550 - heated to $550^{\circ} \mathrm{C}$; Vm - vermiculites; Vm(ss) - Vermiculites sensu stricto; Vm(exp) - vermiculites expandable until $1.65 \mathrm{~nm}$; Int - interstratified micavermiculite minerals; $\mathrm{Mi} / \mathrm{I}$ - mica/illite; Kao - kaolinite. extent, otherwise no recovery of $\mathrm{K}$ by plants will take place. Reversibility of the fixed $\mathrm{K}$ can be expected, as shown by Simonsson et al. (2009). However, the rates of K release must be high enough to meet the crop requirement, which may not occur without fertiliser inputs (Simonsson et al., 2007). Although the recovery by plants of the fixed $\mathrm{K}$ may occur, the interlayer $\mathrm{K}$ must be restored in a great deal until the soils are able to release $\mathrm{K}$ at a sufficient rate for crop growth, especially in rapidly growing crops (Grimme, 1985).

The soils with high $\mathrm{K}$ fixation capacity were derived from gabbros, gabbrodiorites and quarzdiorites, and had relevant amounts of expandable vermiculites and/or interstratified mica-vermiculite minerals, and small amounts of vermiculites sensu stricto either in the clay or in the silt and fine sand fractions. The soils derived from limestones and marls also fixed high amounts of K, particularly the soil S5. As expected, the soil derived from arkoses (soil RC) was the least K fixing soil.

In the studied soils, the relationship between the rates of added $\mathrm{K}$ and the percentage of fixed $\mathrm{K}$ showed distinct patterns, but the correspondence between the pattern of variation and the parent material is only clear for the Alentejo group of soils (Fig. 3). The soils were grouped in three categories. The first group includes soils that exhibit a high percentage of $\mathrm{K}$ fixation at low rates of added $\mathrm{K}$, which drops-off at higher rates of $\mathrm{K}$ addition and then levels off (soils DG and S1, dashed lines, Fig. 2). This behaviour is similar to the general trend of the $\mathrm{K}$ fixation curves described by Shaviv et al. (1985) for some Californian soils and also for soils from other geographical regions, such as Morocco (Bouabid et al., 1991), Northern France (Schneider, 1997), India (Dhaliwal et al., 2006) and Iran (Najafi-Ghiri and Abtahi, 2013), in soils developed on very different parent materials and with different phyllosilicate assemblages. The second group encompasses soils whose $\mathrm{K}$ fixation capacity remains about constant for all rates of $\mathrm{K}$ addition (soils LM, RC and S5, dotted lines, Fig. 2). This pattern is hardly found in literature, but in early studies of $\mathrm{K}$ fixation was observed by MacLean (1962) in Canadian soils for rates of $\mathrm{K}$ application up to $286 \mathrm{mg} \mathrm{kg}^{-1}$ and by Gama (1963) for rates of $\mathrm{K}$ application up to $1048 \mathrm{mg} \mathrm{kg}^{-1}$ in some Portuguese soils. Finally, the third group includes soils in which the percentage of fixed $\mathrm{K}$ increases with progressive levels of $\mathrm{K}$ application (up to $400 \mathrm{mg} \mathrm{kg}^{-1}$ ), as exhibited by soils from the Alentejo region (Fig. 3). While this last group consists of soils developed on the same category of rocks (intermediate/mafic magmatic or metamorphic), the other groups (Fig. 2) do not show a definite relationship with parent material. As far as the authors are aware, the pattern of $\mathrm{K}$ fixation in soils from Alentejo region has not been previously reported.

Potassium fixation in the soil DG $(\sim 40 \%)$ may be due to its high content of mica/illite minerals ( $>60 \%$ ) with frayed edges and enlarged interlayer spaces, as noted by Fanning et al. (1989) and Shaviv et al. (1985), since the other minerals with potential to fix K are only present in low percentage. The importance of weathered mica minerals in selectivity and fixation of $\mathrm{K}$ in wedge sites was emphasized by Rich (1968) and discussed as a function of K concentration in the soil solution. The role of frayed edges in K fixation is also well supported by Sawhey $(1970,1972)$ and reviewed by Fanning et al. (1989). For the soil S1, which had the same pattern of $\mathrm{K}$ fixation as soil DG, its rather high $\mathrm{K}$ fixation capacity ( $\sim 50 \%$ ) is hard to explain. As with soil DG, the main phyllosilicates in the clay fraction of soil S1 (Tables 4 and 5) are mica weathered minerals (10-30\%), and also smectites (10-30\%). This last group of minerals generally has low contribution to $\mathrm{K}$ fixation (Borchardt, 1989; Sawhney, 1970; Sparks and Huang, 1985). However, the presence of residual mica cores surrounded by wedge sites (Borchardt, 1989) and/or the presence of tetrahedral charge (Badraoui and Bloom, 1990; Bouabid et al., 1991) in certain smectites can explain the cation fixation in some soils rich in these minerals. The mineralogy of the clay fraction of soil S1 cannot explain the large quantity of fixed $\mathrm{K}\left(446 \mathrm{mg} \mathrm{kg}^{-1}\right)$ and its fixation capacity, unless the silt fraction also plays a role, which may be the case. In fact, despite the possibility of incomplete dispersion of silt, this fraction, which represents almost half of the soil fine fraction $(<2 \mathrm{~mm})$, seems to have some mica/illite 
minerals. The dominant mineral in all granulometric fractions of soil S1 is calcite, whose participation in $\mathrm{K}$ fixation is not clear. In a study carried out by Najafi-Ghiri and Abtahi (2013) a high K fixation in soils rich in carbonates has been reported. Such a high $\mathrm{K}$ fixation was ascribed by these authors to an appreciable content of mica in the silt and sand soil fractions. Soils with the above-mentioned characteristics were able to fix high amounts of $\mathrm{K}$ (up to $550 \mathrm{mg} \mathrm{kg}^{-1}$ ) under dry conditions and with increased incubation times (Najafi-Ghiri and Abtahi, 2012). In their study, the authors emphasize the role of carbonates as cementing agents in the physical entrapment of $\mathrm{K}$ ions in the soil coarse aggregates.

The soil S5 exhibits a high and constant fixation capacity (near $80 \%$ ) with increasing rates of $\mathrm{K}$ application. This soil, also rich in calcite, has relatively high amounts of potentially $\mathrm{K}$ fixing minerals, like mica/illite and expandable vermiculites, in both clay and silt fractions when compared with soil S1. The role of these phyllosilicate minerals in the K fixation is well documented (Douglas, 1989; Fanning et al., 1989; Sawhney, 1970, 1972). In contrast, soils LM and RC show the lowest K fixation capacity $(\sim 30 \%)$. In fact, the main phyllosilicate minerals present in these soils are smectites, which, as already stated, generally has a low contribution to $\mathrm{K}$ fixation.

The fixation capacity of soil BL must be principally ascribed to the occurrence of expandable vermiculites (30-60\%) in the silt fraction. In addition, small amounts of mica/illite and vermiculite minerals occur in coarser fractions (Table 5). The importance of vermiculites in soil $\mathrm{K}$ fixation has been reported by Barshad (1954) and Murashkina et al. (2007b), and reviewed by Douglas (1989). The other three soils from the Alentejo region (VA, LG and AZ) behave in a similar way to soil BL, though they fixed much more $\mathrm{K}\left(316-346 \mathrm{mg} \mathrm{kg}^{-1}\right.$ and $79-86 \%$ of added $\mathrm{K}$ ) for an application rate of $400 \mathrm{mg} \mathrm{kg}^{-1}$. In comparison with soil BL, they have a lower clay content (Table 2), but instead of smectites, the dominant minerals in that fraction of these soils are weathered mica, interstratified mica-vermiculite minerals, and low percentage of vermiculites (Table 4). Moreover, the same K fixing minerals also occur in the coarser fractions, together with vermiculites. The presence of these minerals in such fractions is currently subscribed by several authors (e.g. Douglas, 1989; Fanning et al., 1989) and was also reported by Abreu and Vairinho (1990), Fonseca et al. (2002) and Monteiro et al. (2002) for soils from Alentejo. In fact, the mild weathering conditions characteristic of the areas with a Mediterranean type of climate accounts for the occurrence in coarser soil fractions of minerals at different stages of weathering, and 2:1 phyllosilicates, including $\mathrm{K}$ fixing minerals. Given the mineralogical composition and the magnitude of the fine sand fraction, its contribution to the $\mathrm{K}$ fixation is relevant in soils VA, LG and AZ. Barshad (1951) reported that a large part of $\mathrm{K}$ fixation was found to reside in the coarser fraction of the soils associated with vermiculite-type minerals. Murashkina et al. (2007a, 2007b) also found considerable amounts of $\mathrm{K}$ fixation in the silt and very fine sand fractions, which were actually more active than the clay fraction in $\mathrm{K}$ fixation. These authors found that the silt fraction was dominated by vermiculite and hydrobiotite (i.e. weathered mica).

The soils from the Alentejo group are peculiar in the sense that all the three soil size fractions contain $\mathrm{K}$ fixing minerals, as vermiculites, interstratified mica-vermiculite and/or weathered mica minerals. Soils rich in weathered mica minerals with frayed edges hold $\mathrm{K}$ selectively in their wedge zones at low concentrations of $\mathrm{K}$, while those with vermiculites fix K if its concentration rises to high levels (Rich, 1968). According to this author, at low concentrations of $\mathrm{K}$ there is a preference for $\mathrm{K}$ in the wedge zones, but with an additional increase in $\mathrm{K}$ concentration, the phyllosilicate layers, where exchange began, tend to collapse and ions are entrapped deeper within the mineral. However, Rich (1968) also argues that for vermiculites, where wedge zones are absent, a larger concentration of $\mathrm{K}$ in the soil solution is necessary to initiate collapse of the vermiculite layers; below this concentration $\mathrm{K}$ selectivity is expected to be low. It must be pointed out that the unusual $\mathrm{K}$ fixation pattern of the soils from Alentejo could also be explained by the long incubation period adopted ( 60 days) compared with the short term extraction procedures used in most $\mathrm{K}$ fixation studies. The long incubation period used in the present study may have allowed an increased $\mathrm{K}$ fixation by the minerals present in the silt and fine sand fractions (Tables 2, 4 and 5). The importance of incubation time has already been emphasized by Najafi-Ghiri and Abtahi (2012), and by Schneider et al. (2013), particularly in soils with low-K status. Since K fixation is a diffusion-controlled process, it depends on time. This becomes relevant in coarse-textured soils, because equilibrium will be obtained more slowly in coarser than in finer fractions. After $\mathrm{K}$ applications to coarser soils (AZ, LG and VA, Table 2), the elevated K concentration in soil solution (Table 3 ) may have increased $\mathrm{K}$ fixation because of their low CEC and low buffer power. This is due to the longer diffusion path into the interlayers of mica/illite and vermiculite-type minerals present in the larger-sized particles of the soils (Table 5) as suggested by Najafi-Ghiri and Abtahi (2012).

Soil parent material seems not to be the main factor influencing the soil $\mathrm{K}$ fixation, except in soils derived from carbonate rocks (S1, S5 and DG), which exhibit high capacity of $\mathrm{K}$ fixation. In the other soils, the main role in the soil $\mathrm{K}$ fixation should be ascribed to the mineralogical assemblage, both in fine and coarse size fractions. Two of these soils (LM and RC), have a low capacity of K fixation (around 30\%), whereas the soils belonging to the Alentejo group fix between 50 and $80 \%$ of the $\mathrm{K}$ added (Table 3 and Fig. 3). This last group of soils contains relevant amounts of $\mathrm{K}$ fixing minerals (Tables 4 and 5) including expandable vermiculites, which can also be able to release some of the previously fixed $\mathrm{K}$.

For the practical purpose of soils fertilisation and based on field experiments performed in the past years the soils from carbonate rocks need very large amount of $\mathrm{K}$ fertiliser $\left(>1000 \mathrm{~kg} \mathrm{~K} \mathrm{ha}^{-1}\right.$ ) to obtain significant yield increase in olive orchards as demonstrated by Jordão et al. (2009). However, a rate of application of $200-400 \mathrm{~kg} \mathrm{~K} \mathrm{ha}^{-1}$ could significantly increase productivity of the olive orchards in soils from Alentejo, as reported by Brito (1970) and Milheiro (1982). This suggests that soils from the Alentejo region are able to release $\mathrm{K}$ at lower fertilisation rates, being the $\mathrm{K}$ more readily available for crops, which also indicates a notable $\mathrm{K}$ reversibility.

From an agronomic point of view, a simple $\mathrm{K}$ fixation test that reflects the $\mathrm{K}$ fixation potential of these type of soils must be designed for making K-fertiliser recommendations. Specific studies to search for fertilisation practices to increase $\mathrm{K}$ uptake in $\mathrm{K}$ fixing soils are needed, because the rates of $\mathrm{K}$ application to the soil may lead to large investments to build up the soil $\mathrm{K}$ levels until the system becomes profitable. This may need to be accompanied by other forms of crop management to ensure profitability.

\section{Conclusions}

The soils under study are low-K status, and can be considered as poor or K depleted soils, exhibiting high $\mathrm{K}$ fixation capacity. The soils with high $\mathrm{K}$ fixation capacity are those formed from carbonate rocks, and from gabbros, gabbrodiorites and quarzdiorites. Consequently, the high potential of K fixation of some Portuguese soils must be the cause of the inefficacy of $\mathrm{K}$ fertilisation reported in soils developed on these types of parent materials.

The soils derived from the above mentioned intermediate/mafic magmatic or metamorphic rocks showed a different pattern of $\mathrm{K}$ fixation that was not previously reported, that is the $\mathrm{K}$ fixation percentage increases with progressive levels of $\mathrm{K}$ addition. The presence in relevant amounts of $\mathrm{K}$ fixing minerals (vermiculites, weathered mica/illite minerals and interstratified mica-vermiculites) in the different particle size fractions of those soils.

Special attention should then be given to the mineralogical characterization of the sand and silt fractions of soils located in regions with a Mediterranean type of climate because, besides the clay fraction, coarser-size soil particles also play a critical role in the soil $\mathrm{K}$ fixation 
behaviour.

\section{Acknowledgements}

Field and sample preparation was provided by José Rego. Chemical analyses were carried out in the Laboratory of Soils and Plants of the University of Trás-os-Montes and Alto Douro. This study was supported by grants from CITAB. This work was also developed in Instituto Superior de Agronomia, Universidade de Lisboa, in the scope of the projects from LEAF (Linking Landscape, Environment, Agriculture and Food Research Centre) - (FCT-UID/AGR/04129/2013), financed by the FCT/MEC through national funds and co-financed by the FEDER within the PT2020 Partnership Agreement, and CEF (Forest Research Centre), financed by the FCT/MEC through the program UID/AGR/00239/ 2013.

\section{References}

Abreu, M.M., Vairinho, M., 1990. Amphibole alteration in a weathering profile of gabbrodiorite. In: Douglas, L.A. (Ed.), Soil Micromorphology: A Basic and Applied Science. Developments in Soil Science 19. Elsevier Sc. Publi., B.V., Amsterdam, pp. 493-500.

Adams, F., 1974. Soil solution. In: Carson, E.W. (Ed.), The Plant Root and Its Environment. University Press of Virginia, Charlottesville, pp. 441-481.

Almeida, L.A.V., 1958. L'útilisation des engrais potassiques au Portugal. In: Kalium Symposium 1958. International Potash Institute, Berne, pp. 65-71.

Alves, J., Nogueira, A., Santos, M.G.B., Santos, A.D., Tavares, M.M.S., 1979. Fertilizacão Mineral e Correcção do Solo I. Fertilização Mineral. Investigação não ligada ao Ensino-Projecto 4. Direcção Geral dos Serviços Agrícolas. Laboratório Rebelo da Silva. III Plano de Fomento (1968-1973). Lisboa, Direcção Geral de Extensão Rural.

Badraoui, M., Bloom, P.R., 1990. Iron-rich high-charge beidellite in vertisols and mollisols of the high Chaouia Region of Morocco. Soil Sci. Soc. Am. J. 54, 267-274.

Barré, P., Velde, B., Fontaine, C., Catel, N., Abbadie, L., 2008. Which 2:1 clay minerals are involved in the soil potassium reservoir? Insights from potassium addition or removal experiments on three temperate grassland soil clay assemblages. Geoderma 146, 216-223. https://doi.org/10.1016/j.geoderma.2008.05.022.

Barshad, I., 1951. Cation exchange in soils: I. Ammonium fixation and its relation to potassium fixation and to determination of ammonium exchange capacity. Soil Sci. $72,361-371$.

Barshad, I., 1954. Cation exchange in micaceous minerals. II-replaceability of ammonium and potassium from vermiculite, biotite and montmorillonite. Soil Sci. 78, 57-76.

Beringer, H., 1985. Adequacy of soil testing for predicting fertilizer requirements. Plant Soil 83, 21-37.

Borchardt, G., 1989. Smectites. In: Dixon, J.B., Weed, S.B. (Eds.), Minerals in Soil Environments, 2nd ed. Soil Science Society of America, Madison, pp. 675-727.

Bouabid, R., Badraoui, M., Bloom, P.R., 1991. Potassium fixation and charge characteristics of soil clays. Soil Sci. Soc. Am. J. 55, 1493-1498.

Brito, F.V., 1970. Contribuição para o estudo dos problemas da fertilização da oliveira. Rev. Agron. 51 (I, II), 3-13.

Cassman, K.G., Roberts, B.A., Kerby, T.A., Bryant, D.C., Higachi, S.L., 1989. Soil potassium balance and cumulative cotton response to annual potassium additions on a vermiculitic soil. Soil Sci. Soc. Am. J. 53, 805-812.

Dhaliwal, A.K., Gupta, R.K., Yadvinder-Singh, Bijay-Singh, 2006. Potassium fixation and release characteristics of some Benchmark Soil Series under rice-wheat cropping system in the Indo-gangectic plains of northwestern India. Commun. Soil Sci. Plant Anal. 37, 827-845. https://doi.org/10.1080/00103620600564174.

Douglas, L.A., 1989. Vermiculites. In: Dixon, J.B., Weed, S.B. (Eds.), Minerals in Soil Environments, 2nd ed. Soil Science Society of America, Madison, pp. 635-674.

Dowdy, R.H., Hutcheson, T.B., 1963. Effect of exchangeable potassium level and drying upon availability of potassium to plants. Soil Sci. Soc. Am. J. 27, 521-523.

Fanning, D.V., Keramidas, V.Z., El-Desoky, M.A., 1989. Micas. In: Dixon, J.B., Weed, S.B. (Eds.), Minerals in Soil Environments, 2nd ed. Madison, Soil Science Society of America, pp. 551-674.

Fonseca, M., Monteiro, F., Madeira, M., Furtado, A.F.A., 2002. A mineralogia e o complexo de troca de solos argiluviados da região de Évora-Beja. Rev. Ciênc. Agrárias 25 (3-4), 42-52.

Gama, M.V., 1963. Fixação de potássio em relação com as quantidades aplicadas nalguns solos. Agron. Lusit. 25, 701-707.

Grimme, H., 1985. The dynamics of potassium in the soil-plant system. In: Proceedings of the 19th Colloquium of the International Potash Institute held in Bangkok, Thailand, pp. 127-154.

Iberian Climate Atlas. Air Temperature and Precipitation (1971-2000), 2011. Agencia Estatal de Meteorología, Ministerio de Medio Ambiente y Medio Rural y Marino and Instituto de Meteorologia de Portugal.

IUSS Working Group WRB, 2006. World reference base for soil resources 2006. In: World Soil Resources Reports No. 103. FAO, Rome.

JCPDS-ICDD, 1996. PDF-2 Data Base (Sets 1-46). Internacional Centre for Diffraction Data, USA.

Jordão, P.V., Marcelo, M.E., Centeno, M.S., Matias, H., Rogado, B., Pinheiro-Alves, M.C.,
Calouro, F., 2009. Influência da fertilização com fósforo e potássio na produção da oliveira e na qualidade do azeite da cultivar Blanqueta em solos derivados de calcário. III Simpósio Nacional de Olivicultura, Castelo Branco. Actas Port. Hortic. 13, 69-76.

Keesstra, S.D., Bouma, J., Wallinga, J., Tittonell, P., Smith, P., Cerdà, A., Montanarella, L., Quinton, J.N., Pachepsky, Y., van der Putten, W.H., Bardgett, R.D., Moolenaar, S., Mol, G., Jansen, B., Fresco, L.O., 2016. The significance of soils and soil science towards realization of the United Nations Sustainable Development Goals. Soil 2, 111-128. https://doi.org/10.5194/soil-2-111-2016.

Kovar, J.L., Barber, S.A., 1990. Potassium supply characteristics of thirty three soils as influenced by seven rates of potassium. Soil Sci. Am. J. 54, 1356-1361.

Kuhlmann, H., 1990. Importance of the subsoil for K nutrition of crops. Plant Soil 127, $129-136$.

LQARS, 2000. Manual de fertilização de culturas. INIA-Laboratório Químico Agrícola Rebelo da Silva, Lisboa.

MacLean, A.J., 1962. Fixation of potassium in some Canadian soils. Can. J. Soil Sci. 42, 96-104.

Marcelo, M.E., 2001. Influência da adubação azotada, potássica e magnesiana em aspectos quantitativos e qualitativos da produção da oliveira. Tese de Doutoramento em Engenharia Agronómica. UTL, ISA, Lisboa.

Mengel, K., Kirkby, E.A., 2001. Principles of Plant Nutrition, fifth ed. Kluwer Academic Publishers, Dordrecht.

Milheiro, A.V., 1982. A fertilização da oliveira. Série Olivicultura DGER, Lisboa nº 1,29 p.

Monteiro, F., Madeira, M., Fonseca, M., 2002. Características físicas, químicas e mineralógicas e comportamento hidrológico de um Solonetz no Sul de Portugal. Rev. Ciênc. Agrárias 25 (3-4), 67-77.

Moore, D.M., Reynolds, R.C., 1997. X-Ray Diffraction and the Identification and Analysis of Clay Minerals, 2nd ed. Oxford University Press, Oxford.

Murashkina, M.A., Southard, R.J., Pettygrove, G.S., 2007a. Potassium fixation in San Joaquin Valley soils derived from granitic and nongranitic alluvium. Soil Sci. Soc. Am. J. 71, 125-132. https://doi.org/10.2136/sssaj2006.0060.

Murashkina, M.A., Southard, R.J., Pettygrove, G.S., 2007b. Silt and fine sand fraction dominate potassium fixation in soils derived from granitic alluvium of the San Joaquin Valley, California. Geoderma 141, 283-293. https://doi.org/10.1016/j. geoderma2007.06.011.

Najafi-Ghiri, M., Abtahi, A., 2012. Factors affecting potassium fixation in calcareous soils of southern Iran. Arch. Agron. Soil Sci. 5, 335-352. https://doi.org/10.1080/ 03650340.2010 .507194$.

Najafi-Ghiri, M., Abtahi, A., 2013. Potassium fixation in soil size fractions of arid soils. Soil Water Res. 8 (2), 49-55.

Novozamsky, I., Houba, V.J.G., 1987. Critical evaluation of soil testing methods for K. In: Methodology in Soil-K Research. 20th Colloquium International Potash Institute, Baden, Austria, pp. 165-185.

Portela, E.A.C., 1993. Potassium supplying capacity of northeastern Portuguese soils. Plant Soil 154, 13-20.

Rich, C.I., 1968. Mineralogy of soil potassium. In: Kilmer, V.J., Younts, S.E., Prady, N.C. (Eds.), Role of Potassium in Agriculture. Soil Science Society of America, Madison, pp. 79-108.

Riehm, H., 1958. Die Ammoniumlaktatetessigsäure Method zur Bestimmung der Leichtlöslichen Phosphorsäure in Karbonathaltigen Böden. Agrochimica 3, 49-65.

Sardi, K., Csitari, G., 2008. Potassium fixation of different soil types and nutrient levels. Commun. Soil Sci. Plant Anal. 29 (11-14), 1843-1850.

Sawhney, B.L., 1970. Potassium and cesium ion selectivity in relation to clay mineral structure. Clays Clay Mineral. 18, 47-52.

Sawhney, B.L., 1972. Selective sorption and fixation of cations by clay minerals: a review. Clays Clay Mineral. 20, 93-100.

Sawhney, B.L., 1989. Interstratification in layer silicates. In: Dixon, J.B., Weed, S.B. (Eds.), Minerals in Soil Environments, 2nd ed. Soil Science Society of America, Madison, pp. 789-828.

Schneider, A., 1997. Release and fixation of potassium by a loamy soil as affected by initial water content and potassium status of soil samples. Eur. J. Soil Sci. 48 263-271. https://doi.org/10.1080/00103624.2013.749442.

Schneider, A., Tesileanu, R., Charles, R., Sinaj, S., 2013. Kinetics of soil potassium sorption-desorption and fixation. Commun. Soil Sci. Plant Anal. 44, 837-849.

Schultz, G.L., 1969. Lithium and potassium absorption, dehydroxylation temperature, and structural water content of aluminous smectites. Clay Clay Miner. 17, 115-149.

Sharpley, N.A., 1990. Reaction of fertilizer potassium in soils of differing mineralogy. Soil Sci. $149,44-51$.

Shaviv, A., Mohsin, M., Pratt, P.F., Mattigod, S.V., 1985. Potassium fixation characteristics of five southern California soils. Soil Sci. Soc. Am. J. 49, 1105-1110.

Simonsson, M., Andersson, S., Andrist-Rangel, Y., Hillier, S., Mattsson, L., Öborn, I., 2007 Potassium release and fixation as a function of fertilizer application rate and soil parent material. Geoderma 140, 188-198. https://doi.org/10.1016/j.geoderma. 2007.04.002.

Simonsson, M., Hillier, S., Oborn, I., 2009. Changes in clay minerals and potassium fixation capacity as a result of release and fixation of potassium in long term field experiments. Geoderma 151, 109-120.

Sparks, D.L., Huang, P.M., 1985. Physical chemistry of soil potassium. In: Munson, R.D. (Ed.), Potassium in Agriculture. American Society of Agronomy, Madison, pp. 201-275.

Velde, B., Meunier, A., 2008. The Origin of Clay Minerals in Soils and Weathered Rocks. Springer-Verlag, Berlin. 